\title{
UMA BREVE RETROSPECTIVA DO DESENVOLVIMENTO DA POLÍTICA DE REFUGIADOS NO BRASIL SOB AS ÓTICAS DA EUGENIA, DA SEGURANÇA NACIONAL E DO UTILITARISMO ECONÔMICO (1889-1997)
}

\author{
A BRIEF RETROSPECTIVE OF THE DEVELOPMENT OF REFUGEE POLICY IN \\ BRAZIL FROM THE POINTS OF EUGENIA, NATIONAL SECURITY AND ECONOMIC \\ UTILITARIANISM (1889-1997)
}

\author{
Thaynara Lima Alves ${ }^{1}$
}

Doi: $10.36066 /$ compcs.v1i23.6345

\begin{abstract}
Resumo: O presente artigo consiste na realização de uma retrospectiva histórica, a partir de marcos legais, do desenvolvimento da política de imigração e, especificamente, da política de refugiados no Brasil durante o período de 1889 até 1997. A análise será orientada através dos parâmetros da eugenia, da segurança nacional e do utilitarismo econômico, considerando a dialética entre o Estado brasileiro, a comunidade internacional e a sociedade civil organizada.
\end{abstract}

Palavras-chave: Refugiados, eugenia, segurança nacional, utilitarismo econômico.

\begin{abstract}
The present article consists in the accomplishment of a historical retrospective, based on legal instruments, of the development of immigration policy and, specifically, of the refugee policy in Brazil during the period from 1889 to 1997. The analysis will be guided by the parameters of eugenics, national security and economic utilitarianism, considering the dialectics between the Brazilian State, the international community and organized civil society.
\end{abstract}

Keywords: Refugee, eugenics, national security, economic utilitarianism.

\section{Introdução}

A destruição de cidades inteiras, o deslocamento massivo e a morte de milhões de pessoas, os danos materiais e psicológicos, a instabilidade sócio-política e econômica, as perseguições com as mais variadas conotações são algumas das numerosas e conhecidas consequências da I Guerra Mundial. Em vista disso, houve a ascensão de uma articulação elencada pela comunidade internacional voltada para a reorganização político-institucional das relações internacionais entre os Estados, com a finalidade de contornar as devastações geradas pela guerra, evitar novos conflitos e, sendo tema focal desta pesquisa, administrar a crescente situação dos que viriam a ser considerados, posteriormente, pelo status de refugiado. Esta situação, por sua vez, causava impactos políticos, sociais, econômicos, culturais tanto no plano nacional dos países envolvidos diretamente com a questão quanto em suas relações internacionais, e que precisavam ser solucionados em caráter de urgência.

\footnotetext{
${ }^{1}$ Graduada em Ciências Sociais - Universidade Federal Rural do Rio de Janeiro. Km 07 ,Zona Rural, BR-465, Seropédica - RJ, 23890-000. Tel:. 55 (21) 2682-1080. thaylimaalves@gmail.com

Compocs, v1, n 23 - jul -dez 2020
} 
Consequentemente, as organizações internacionais e os instrumentos legais referentes à questão dos refugiados criados após este período influenciaram decisivamente nas configurações políticas internas dos Estados, especialmente, no que toca à sistematização do reconhecimento e do tratamento legal e social dos refugiados. Posto isso, buscando trabalhar de forma mais incisiva e específica a temática dos refugiados e seus desdobramentos no campo doméstico, os dados aqui referidos serão basilares para a análise do tratamento desta questão pelo Estado brasileiro, em constante diálogo com o contexto internacional e com as ações internas do país, incluindo a sociedade civil. Ressalta-se que o Brasil teve sua participação no processo de formalização da situação dos refugiados, ora mais ora menos ativa, registrada de acordo com os vários marcos que aqui serão mencionados, mas não se limitando aos mesmos.

\section{Primeira República: heranças e direcionamentos}

Para tratar a política de refugiados em termos de Brasil, é necessário realizar, antes, uma breve contextualização da Primeira República. A sinalização deste contexto é imprescindível para considerarmos o futuro tratamento do Estado brasileiro em relação aos mesmos, dado que que as políticas governamentais são carregadas de heranças desse período, dos mais remotos e, consequentemente, do decorrer de cada época, principalmente no que tange aos fundamentos da eugenia, da segurança nacional e do utilitarismo econômico.

Haja vista que ainda nos primórdios de um Brasil republicano se verificava em partes do Estado e das classes dominantes do país a influência de teorias raciais emergidas na Europa, os trabalhadores nacionais, isto é, principalmente os ex escravos, e os indígenas, eram considerados desqualificados para a etnogênese almejada pelo governo brasileiro ${ }^{2}$. O padrão desejável seria alcançado com imigrantes europeus que, ao contrário de uma grande parcela da população nacional, eram vistos como trabalhadores disciplinados (VAINER, 1990, p. 104-105). As teses eugenistas foram amplamente difundidas no Brasil e, com isso, buscou-se alcançar o ideal de "branqueamento" proposto pelos dirigentes do país em conjunto com a concepção de "desenvolvimento étnico-cultural", dado que o discurso racista, frequentemente, considerava muitos problemas do

\footnotetext{
${ }^{2}$ Constituição de uma nacionalidade e de um povo baseada em critérios étnico-raciais que pressupõem a superioridade de alguns grupos e a desqualificação de outros a fim de atender aos interesses nacionais. Ver mais em "VAINER, Carlos. Estado e raça no Brasil: notas exploratórias. Estudos Afro-Asiáticos n 18. RJ. 1990”.
} 
país, tal como miséria, doenças, analfabetismo resultado de uma "má formação étnica" da maioria dos brasileiros (KOIFMAN, 2017, p. 73). Esta concepção pode ser atestada através de leis que foram colocadas em prática ao longo dos anos seguintes e que caracterizam o ideal de "branqueamento" aqui referenciado.

Dois anos após a abolição formal da escravatura no Brasil, houve a regularização do serviço de introdução e localização de imigrantes no país através do Decreto $\mathrm{n}^{\circ} 528$, de 28 de junho de 1890. Contudo, o art. $1^{\circ}$ deste instrumento definia que a entrada de imigrantes no país era livre somente para os que não estivessem sujeitos à ação criminal do país de origem e que fossem considerados "válidos e aptos para o trabalho (...), excetuando os indígenas da Ásia, ou da África que somente mediante autorização do Congresso Nacional poderão ser admitidos de acordo com as condições que forem então estipuladas" (BRASIL, 1890). Portanto, a atenção inicial dos dirigentes da Primeira República para a imigração estava fortemente atrelada à ascensão do mercado de trabalho assalariado no país como forma de colocar em prática o ideal do "branqueamento", preferenciando a mão de obra europeia e deixando novamente de lado a população nacional já marginalizada durante a escravidão.

Com o passar da Primeira República, a política restritiva de imigração continuou ganhando força, tendo sua conotação racista ora mais ora menos explícita nas legislações. Através do Decreto $\mathrm{n}^{\circ}$ 4.247, de 6 de janeiro de 1921, foi regulada a entrada de estrangeiros no país. Partindo de uma concepção utilitarista e preconceituosa, seu art. $1^{\circ}$ era orientado por uma seleção física que impedia a entrada de imigrantes "mutilado, aleijado, cego, louco, mendigo, portador de moléstia incurável ou de moléstia contagiosa grave”. Igualmente, eram deixados de lado os que se prestavam à prostituição ou que tivessem mais de 60 anos. Além disso, coloca-se como critério de expulsão do território nacional, segundo o art. $2^{\circ}$ do instrumento referido, condutas que fossem consideradas nocivas “à ordem pública ou à segurança nacional” (BRASIL, 1921). Vale frisar que o critério de seleção física, legado da escravidão e de uma lógica baseada no utilitarismo econômico, juntamente com o fundamento da segurança nacional, permaneceu sendo utilizado pelas autoridades brasileiras por muito tempo no tratamento dos imigrantes e, consequentemente, incidindo sobre os refugiados, como veremos.

\section{Era Vargas: Guerras Mundiais, nazi-fascismo e anticomunismo}

A aproximação inicial do Brasil, mesmo que apenas de maneira superficial, com a temática dos refugiados pode ser vista sob uma ótica de interesses econômicos, políticos e socioculturais das 
autoridades brasileiras que seguem, principalmente, os acontecimentos decorrentes das duas Grandes Guerras, da ascensão do nazi-fascismo, da ideologia anticomunista e de uma concepção eugenista. Esses fatores resultaram em perseguições com conotações política, ideológica, étnica, racial, religiosa e de orientação sexual, que ora se combinavam. Com isso, houve um aumento do contingente de pessoas que fugiam de vários países, dentre eles da Alemanha e da Itália, e buscavam refúgio no Brasil.

Nessa mesma conjuntura, houve a implementação de políticas imigratórias mais restritivas por parte do Brasil com a chegada da Era Vargas (1930-45), tendo uma fase mais intensa na vigência do Estado Novo (1937-45). Ainda sob uma ótica utilitarista, a Constituição de 1934, por meio dos Decretos-Lei $n^{\circ} 24.215$ e ${ }^{\circ} 24.258$, respectivamente, de 9 e 16 de maio do mesmo ano, abarcava e tratava de forma mais árdua todas as definições referentes aos imigrantes. Além disso, as restrições foram ampliadas aos surdos, aos ciganos e aos nômades (BRASIL, 1934a; Idem., 1934b). Se antes as condutas morais e políticas dos estrangeiros deveriam ser, de acordo com o Decreto $\mathrm{n}^{\circ}$ 4.247, de 1921, compatíveis com os ditames da ordem pública e da segurança nacional, com a Constituição de 1934 essas lógicas ganham uma nova potência. Assim, em vista do enrijecimento da política brasileira a partir de 1934, a questão da imigração passou a ser cada vez mais atrelada, não por acaso, a esses ditames.

Como exemplo, ressalta-se o episódio conhecido como "Intentona Comunista", em 1935, liderado pela Aliança Nacional Libertadora (ANL) e derrotado por uma forte repressão. O movimento resultou na união das elites políticas e na relevância do mito da conspiração judaico-comunista (MAIO, 1999, p. 239-242). Além de inflamar a campanha anticomunista no país, serviu como justificativa para o fortalecimento do regime e de suas medidas de exceção, combinando perseguições de conotação político-ideológica, étnico-racial e religiosa. Assim, tendo em vista que a posição comunista é classificada como uma influência externa e a presença de judeus no país como resultado da imigração, o fato de o movimento ter ocorrido em território nacional reforçou, juntamente com os esforços do governo e da imprensa anticomunista, a concepção, frente a população, de que era necessária uma política de imigração mais controlada. Desse modo, se antes o inimigo era encarado como, predominantemente, externo, a "Intentona" consolidou a imagem de um inimigo presente internamente, acalorando os debates sobre segurança nacional, imigração e refúgio.

Ao aflorar esses debates, a "Intentona" também mudou a opinião dos, até então, contrários Compocs, v1, n 23 - jul -dez 2020 
às decisões da Lei de Segurança Nacional (Lei ${ }^{\circ} 38$ de 4 de abril de 1935), que definia os crimes contra a ordem política e social do país. A lei possibilitou a repressão de atividades políticas consideradas subversivas e teve seu aperfeiçoamento durante a continuidade do governo (BRASIL, 1935; CAPELATO, 2003, 115-131). Além disso, veremos que a Lei permaneceu nas constituições brasileiras mesmo após o fim do Estado Novo, servindo de base para as subsequentes políticas imigratórias do país, incluindo o tratamento de refugiados. E será retomada com um novo vigor durante o regime ditatorial de 1964-1985.

Ainda sobre a Constituição de 1934, vale salientar o estabelecimento de um sistema de cotas de imigração que não permitia um percentual anual maior que $2 \%$ de imigrantes de cada país sobre o número total dos respectivos nacionais estabelecidos no Brasil nos últimos cinquenta anos. Proibiu-se também a concentração de estrangeiros de uma mesma nacionalidade em qualquer ponto do território brasileiro (GUIMARÃES; VAINFAS, 2000, p. 110-111). Essa tentativa de fixar um limite de estrangeiros no Brasil pode ser vista através da política de nacionalização promovida durante a Era Vargas, objetivando o caldeamento de todos os imigrantes e seus descendentes considerados "não-assimilados", isto é, que possuíam culturas qualificadas como incompatíveis com os princípios da brasilidade planejada, e a desconcentração dos, pejorativamente, chamados "quistos étnicos" ou "quistos raciais", onde havia núcleos de grupos étnicos formados no processo imigratório. Estes eram classificados pela categoria de "alienígena" na campanha concebida como uma "guerra" que visava a erradicação de concepções que vinham dos mesmos a fim de impor um fundamento nacional aos que formavam esses quistos (SEYFERTH, 1997, p. 95). Observa-se que a concepção xenofóbica da política imigratória encontra no fundamento da segurança nacional uma justificativa para selecionar e controlar os imigrantes de acordo com os interesses nacionais.

O Estado Novo foi marcado por um intenso autoritarismo através do controle político, social e cultural e pela restrição das liberdades em muitas dimensões com a dura Constituição de 1937. Perpassando um contexto de II Guerra Mundial, o governo brasileiro buscava se distanciar das comparações com os regimes nazifascistas a fim de afirmar a originalidade do Estado Novo, todavia, o mesmo colocou em prática ideias semelhantes as destes regimes, tais como a legislação social, a propaganda política, a representação corporativista e o antissemitismo (CAPELATO, 2003, p. 131-135). Ademais, a Constituição de 1937 sinalizava em seu preâmbulo os fundamentos de suas práticas, destacando que atende ao "estado de apreensão criado no país pela infiltração comunista, que se torna dia a dia mais extensa e mais profunda, exigindo remédios, de caráter radical e permanente" (BRASIL, 1937). Compocs, v1, n 23 - jul -dez 2020 
Com a criação do Conselho de Imigração e Colonização (CIC) pelo Decreto-Lei ${ }^{\circ} 406$, de 4 de maio de 1938, como órgão regulador da política imigratória em território nacional, o Estado passou a ter total controle sobre a seleção da entrada, da nacionalidade, da extradição e da expulsão dos imigrantes no país. $\mathrm{O}$ art. $2^{\circ}$ do referido decreto possibilitava que o governo limitasse ou suspendesse "por motivos econômicos ou sociais, a entrada de indivíduos de determinadas raças ou origens, ouvido o Conselho de Imigração e Colonização" (BRASIL, 1938). Ao aprovar o regimento do CIC pelo Decreto $\mathrm{n}^{\circ}$ 3.691, de 6 de fevereiro de 1939, colocava-se como finalidade do órgão "estudar os problemas relativos à seleção imigratória, à antropologia étnica e social, à biologia racial e à eugenia", em função do desenvolvimento de medidas para "promover a assimilação e evitar a concentração de imigrantes em qualquer ponto do território nacional” (BRASIL, 1939).

Posto isso, pode-se reconhecer o grande impacto das teorias eugenistas, de cunho europeu e norte-americano, na formulação de política imigratória do país, principalmente tendo em vista que as reflexões de importantes intelectuais brasileiros, orientados por essas teorias, influenciaram diretamente na formulação dessa política. A título de exemplo, cita-se Oliveira Vianna, importante peça no desenvolvimento do pensamento nacionalista brasileiro, que ilustrou o viés restritivo da política imigratória do país como uma forma de selecionar os estrangeiros que poderiam contribuir positivamente para formação da nacionalidade brasileira, isto é, trabalhando a terra ou trazendo capitais e se assimilando ao resto da população (GRINBERG, 2007, p. 135). Ao considerar a miscigenação no Brasil caótica, o autor sinaliza a inferioridade das "raças bárbaras" (negros e índios) e o processo de "arianização" mediante o aumento do coeficiente branco pela imigração e pela estagnação da população negra e mestiça (SEYFERTH, 2002, p. 133).

Vale evidenciar que o conceito de "assimilação", segundo autores como Oliveira Vianna, descartava os judeus, que eram vistos sob o estereótipo de moradores de grandes cidades e dirigentes de comércios, além de preservarem seus idiomas de origem e educarem seus filhos de acordo com suas tradições (GRINBERG, 2007, p. 135). Essa visão colocava os judeus como não interessados em trabalhar em áreas rurais, que era uma das orientações da política imigratória do país, e resistentes à "assimilação" por preservarem sua identidade cultural. Ademais, por fundarem no Brasil instituições que reuniam suas tradições, contrariavam a política de concentração de pessoas de uma mesma origem nacional em determinados pontos do território, que, por sua vez, foi formulada como resposta a esse fenômeno de associação realizado também por vários outros grupos.

O antissemitismo no Brasil foi explicitamente verificado na restrição à imigração de 
refugiados judeus durante as circulares secretas, que chegaram a proibir a concessão de vistos a pessoas de origem semita, inclusive de imigrantes turistas e negociantes (GRINBERG, 2007, p. 130). Também se verificava a presença de correspondências antissemitas nos ministérios, nas missões diplomáticas brasileiras e na publicação de obras integralistas e católicas de caráter anti-judaico. A repressão sobre as questões de origem estrangeiras foi intensificada a ponto de desativar sistemas educacionais implantados pelas comunidades alemãs, polonesas e italianas radicadas no Brasil, censurar a utilização da língua de origem e prender os identificados como judeus, que foram frequentemente associados aos comunistas (CARNEIRO, 1994, p. 163).

O CIC também tinha como incumbência orientar a política imigratória para a colonização do território brasileiro e, com a chamada Marcha para o Oeste, iniciada por Vargas, houve a tentativa de proteger o território a partir do povoamento para as terras do interior, visto que as regiões litorais, até o momento, constituíam-se como as áreas de maior densidade populacional, em função da política mercantilista colonial e da falta de infraestrutura dos meios de transporte em outras regiões. Assim, o governo Vargas combinou duas de suas grandes preocupações: o povoamento do território, atrelado à colonização, e a política imigratória. Desse modo, os estrangeiros eram conduzidos aos trabalhos do campo sem prejuízo para o trabalhador nacional, contribuindo no povoamento do território a partir da seleção dos que estivessem de acordo com as orientações governamentais (GOMES, 1999, p. 68-69).

A Marcha para o Oeste permitiu, portanto, que o governo guiasse sua política de imigração segundo a seleção de estrangeiros desejáveis, ocultada pela concepção de "assimilação", que, por sua vez, envolvia critérios para o "aperfeiçoamento étnico-cultural" da sociedade e, consequentemente, para o projeto nacionalista promovido pelo menos. Além disso, possibilitava o controle sobre a concentração de imigrantes em determinadas regiões, dado que o governo poderia distribuí-los em diferentes áreas a fim evitar a resistência de grupos mais concentrados à "assimilação" ao meio brasileiro. Portanto, havia um projeto de homogeneidade cultural orientada pelo ideal do "branqueamento" sob a ótica de integração da pátria para preencher os espaços vazios do território.

Com o desenrolar da II Guerra Mundial e a grande geração de refugiados e migrantes involuntários, o grau de seletividade de estrangeiros pelo Brasil foi reforçado. Com o Decreto-Lei $\mathrm{n}^{\circ} 3.175$, de 7 de abril de 1941, suspendeu-se a concessão de vistos temporários e permanentes para a entrada de estrangeiros no Brasil, com as suas devidas exceções. Segundo o art. $1^{\circ}$ do referido decreto, os vistos temporários só eram concedidos a nacionais de Estados americanos e a 
estrangeiros de outras nacionalidades que pudessem comprovar meios de subsistência. No entanto, era colocado como condição que todos os estrangeiros estivessem autorizados a voltar aos Estado onde obtêm o visto ou de que é nacional (BRASIL, 1941). Ou seja, sob a ótica da prerrogativa de retorno, muitos refugiados e apátridas tinham seus vistos de entrada recusados pela falta de garantia de repatriamento ou de volta ao país que residiam.

No entanto, o argumento do retorno era utilizado para camuflar os pretextos políticos, sociais e, sobretudo, raciais da política imigratória brasileira. $\mathrm{O} \S 1^{\circ}$ do art. $3^{\circ}$ do Decreto-Lei $\mathrm{n}^{\circ}$ 3.175 ainda frisava que o Ministério da Justiça e Negócios Interiores, agora incutido da autorização do visto, verificaria se o estrangeiro possuía os atributos físicos e morais requeridos pela legislação, se tem aptidão para os trabalhos a que se propõe e condições de assimilação ao meio brasileiro (BRASIL, 1941). Isto é, através dessa seleção eram deixadas de lado pessoas que não atendiam aos critérios da campanha de nacionalização, a dizer negros, orientais, isto é, "não brancos", além de comunistas, judeus e deficientes.

O Decreto-Lei $n^{\circ} 3.175$ foi revogado pelo Decreto-Lei ${ }^{\circ} 7.575$, de 21 de maio de 1945, suspendendo a restrição de estrangeiros no Brasil em função de motivos de ordem política e "por lhe parecer conveniente facilitar desde já a imigração dos países europeus para o Brasil” (BRASIL, 1945a). Assim, apesar da suposta desvinculação da seleção de estrangeiros segundo critérios políticos, diminuindo sua ligação direta com a noção de segurança nacional orientada com vista nos interesses governamentais, houve a preservação da preferência de imigrantes de origem europeia no país, reforçando o critério de seleção étnico-racial.

Portanto, norteada por um viés eugenista que visava o "aperfeiçoamento étnico-cultural" dos brasileiros, via imigrantes de origem europeia, a política imigratória do Brasil evidenciava a lógica presente desde a Primeira República e, mais remotamente, o período da Colônia. Esta postura foi reafirmada, já no fim do governo Vargas, com o Decreto-lei n ${ }^{\circ} 7.967$, de 18 de setembro de 1945, que, considerando o fim da II Guerra Mundial, tinha seu art. $2^{\circ}$ definindo que "atender-se-á, na admissão dos imigrantes, à necessidade de preservar e desenvolver, na composição étnica da população, as características mais convenientes da sua ascendência européia, assim como a defesa do trabalhador nacional" (BRASIL, 1945b).

Posto isso, tratar o quadro dos refugiados por um viés humanitário, principalmente por conta de seu destaque nas discussões internacionais, impossibilitava a seleção étnico-racial dos estrangeiros que entrariam no país, configurando-se em um entrave para a política eugenista do governo brasileiro. Para contornar essa situação, o governo adotou uma posição pautada na 
segurança nacional e na ordem pública, colocando os refugiados sob fundamentos de cunho político e social para disfarçar o preceito racista que orientava a política imigratória, uma vez que as posturas nazistas e fascistas se tornaram alvos de julgamento, pelo menos formalmente, para os que se posicionavam contrários aos seus atos. Essa atitude é evidenciada tendo em vista a polarização dos países participantes da II Guerra segundo os blocos capitalista e socialista, que orientavam suas respectivas políticas.

\section{Transição: pressões do cenário internacional e implementação inicial da política de refugiados no Brasil}

No cenário internacional, a discussão sobre os direitos humanos foi se tornando uma pauta de grande relevância, principalmente por conta das discussões iniciadas no âmbito da Organização das Nações Unidas (ONU). Esse contexto tornava a situação cada vez mais complexa para ser tratada no domínio brasileiro, dado que o país passava por uma ditadura que violava os direitos de seus próprios nacionais. Por conseguinte, o governo brasileiro se viu na necessidade de realizar um esforço para conciliar suas linhas ditatorial e diplomática no conjunto de suas relações internacionais e nacionais. Assim, tentou evitar que as influências do cenário internacional, isto é, a vitória dos aliados na II Guerra e a consequente crítica às ditaduras, chegassem ao âmbito nacional e ameaçassem a vigência do regime. Contudo, o empenho do governo Vargas não foi suficiente para deixar a validade do regime fora de pauta e o caminho seguido foi o da redemocratização. Com

isso, seguiu-se também o processo de abertura da política imigratória no país, especificamente no que tange aos refugiados, mas com a permanência de alguns fundamentos restritivos na condução dessa política.

Findada a II Guerra Mundial e iniciado o regimento da ONU, o Brasil encontrou como forma de mostrar seu apoio aos países do Bloco Ocidental a inclinação para a questão dos refugiados, aceitando o reassentamento de refugiados e deslocados de guerra europeus no país. Todavia, quando a Constituição da Organização Internacional para os Refugiados (OIR) foi votada, em 15 de dezembro de 1946, o Brasil foi um dos 18 países que se absteve, demonstrando que apesar de estar cooperando com o Bloco Ocidental, ainda não possuía grande interesse sobre a problemática dos refugiados (ANDRADE, 2005, p. 2-4).

Em vista do grande número de refugiados e da crise humanitária decorrentes da II Guerra Mundial, a política imigratória do Brasil teve que ser repensada para abarcar essas mudanças. $\mathrm{O}$ art. 
Compocs, v1, n 23 - jul -dez 2020

162 da Constituição de 1946 do Brasil definia que a "seleção, entrada, distribuição e fixação de imigrantes ficarão sujeitas, na forma da lei, às exigências do interesse nacional” (BRASIL, 1946). Assim, acoplando seus interesses políticos e socioeconômicos, o governo Dutra passou a considerar o recebimento de imigrantes e de refugiados com base no desenvolvimento industrial do país, preferenciando aqueles com alguma qualificação profissional e preservando a concepção eugenista que orientou os períodos anteriores, como veremos a seguir.

A abertura da política imigratória do Brasil, apesar de ter seguido um curso lento e burocrático, teve um grande avanço quando, em 1946, o Brasil e o Comitê Intergovernamental, órgão temporário encarregado de milhares de pessoas na condição de refugiados e deslocados na Europa, começaram a negociar a real possibilidade de o Brasil receber um número destes mediante um acordo jurídico. O presidente Dutra enviou três comissões de seleção à Europa, devendo ser, idealmente, compostas por um chefe, um funcionário indicado pelo Ministério do Trabalho, um cônsul, um médico, um secretário e um intérprete. No entanto, não havia instruções formais para os critérios de seleção dos refugiados e deslocados ou um cadastro da mão-de-obra necessitada no Brasil, que deveria ter sido feito pelo Conselho de Imigração e Colonização, conforme o art. 97 de seu regimento. Em substituição, os critérios adotados seguiam as orientações dos chefes das comissões de seleção e de Artur Hehl Neiva, conselheiro do CIC (ANDRADE, 2005, p. 15-16).

Em 1947, depois de três meses de trabalho na Europa, Neiva enviou um relatório com sugestões para a seleção dos refugiados e deslocados, recomentando a preferência por baltas (lituanos, letões e estonianos), ucranianos, poloneses, russos brancos (não comunistas) e iugoslavos, nesta ordem de prioridade. Em 1 de abril do mesmo ano, foi concluído o Acordo entre o Governo dos Estados Unidos do Brasil e o Comitê Intergovernamental de Refugiados, no qual o Brasil receberia um primeiro grupo de refugiados e deslocados, a título de experiência, de mil famílias, não devendo exceder o total de cinco mil indivíduos. O Brasil ficou responsável pela seleção, recepção, encaminhamento e colocação profissional dos refugiados. As despesas decorrentes do transporte e a contribuição, com até cem mil dólares, para as despesas de melhorias das condições de recebimento e de estabelecimento de centros de orientação teriam de ser de responsabilidade do Comitê. Contudo, esse acordo não completou a cota de 5 mil refugiados e deslocados, chegando no país apenas 2.511 (ANDRADE, 2005, p. 16-19).

A seleção dos refugiados e deslocados que entrariam no Brasil se tornou um assunto de grande relevância pública, suscitando discussões em várias esferas e chamando a atenção da imprensa, tal como ilustrado na edição de 22 de novembro de 1948, do jornal "A Noite": 
Figura 1 - Jornal "A Noite" traz a manchete "Novos métodos de seleção de imigrantes adotados pela OIR".

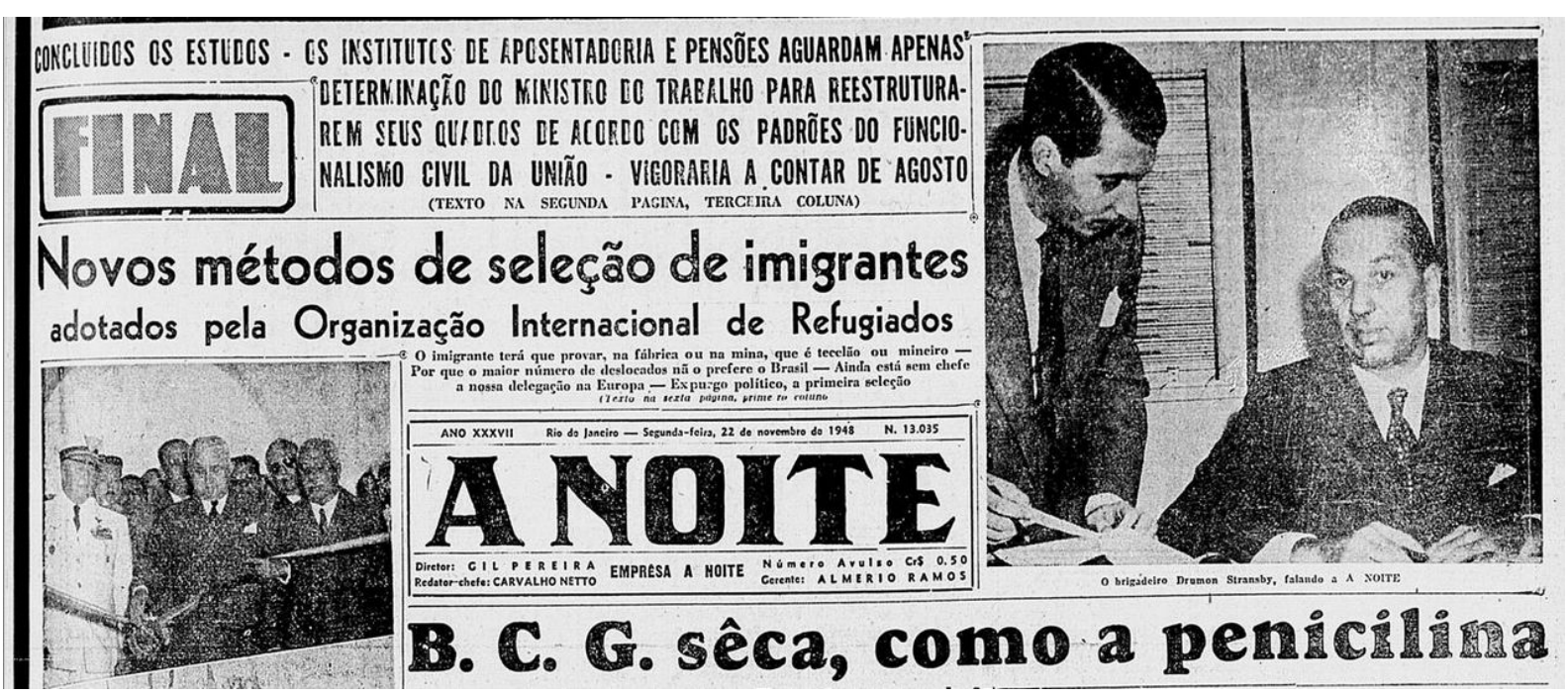

Fonte: Trecho da edição de 22 de novembro de 1948 do jornal "A Noite". 3

$\mathrm{Na}$ manchete intitulada "Novos métodos de seleção dos imigrantes adotados pela Organização Internacional de Refugiados”, há a cobertura de uma coletiva realizada pelo brigadeiro Dumon Stansby, então chefe da Missão da OIR no Brasil. Segundo a manchete, o brigadeiro declara que o número de imigrantes que o Brasil recebe é insignificante se comparado aos de outros países da América Latina, justificando que o sistema de recepção e colocação para as fazendas, minas e fábricas não comporta um aumento nesse fluxo. Além disso, Stansby toca no fato de que os refugiados nos campos de concentração deveriam ser convencidos a virem para o Brasil em meio à propaganda de outros países que buscavam por mão-de-obra para suas lavouras e indústrias.

Ainda de acordo com a manchete, ao abordar sobre o novo método de seleção realizado pela OIR, Dumon Stansby aponta que se antes bastava o imigrante declarar sua profissão para que ficasse registrado em sua ficha, agora era necessário comprovar suas atividades na prática. Ou seja, se os imigrantes se declarassem tecelões, estes eram mandados pela OIR para uma fábrica de tecidos para serem apreciados por um técnico e receberiam um certificado para autenticar suas habilidades. Essa mudança visava evitar que os fazendeiros ou os industriais que recebessem os imigrantes tivessem inconvenientes. Além do critério profissional, o brigadeiro cita que os imigrantes eram selecionados de acordo com suas ideias políticas, com o intuito de evitar nazistas e comunistas. Havia também uma seleção econômica, custeando os transportes dos desprovidos de

\footnotetext{
${ }^{3}$ Disponível em: <http://memoria.bn.br/docreader/DocReader.aspx?bib=348970_04\&PagFis=55591\&Pesq=>. Acesso em 15 de janeiro de 2018.

Compocs, v1, n 23 - jul -dez 2020
} 
recursos financeiros, exame médico para selecionar os fisicamente aptos e a havia exigência de que todos os imigrantes da OIR soubessem ler e escrever. Por fim, após serem aceitos em todos esses critérios, os imigrantes seriam apresentados às comissões de seleção dos diversos países para que estes pudessem escolher os imigrantes de acordo com suas conveniências.

Portanto, saúde, capacitação para o trabalho, orientação político-ideológica, grau de instrução e origem europeia eram alguns dos critérios que norteavam as comissões de seleção dos refugiados e deslocados, demonstrando a permanência dos fundamentos que regiam as políticas imigratórias anteriores. A atenção humanitária dada aos refugiados e deslocados deveria estar de acordo com os interesses nacionais, isto é, para afirmar o posicionamento ao lado dos países do bloco capitalista e considerar esses estrangeiros como uma forma de alcançar o desenvolvimento socioeconômico do país.

Posteriormente, em 30 de abril de 1948, foi estabelecido o Acordo Administrativo entre o Governo dos Estados Unidos do Brasil e a Comissão Preparatória da OIR, com sua implementação interna através do Decreto $\mathrm{n}^{\mathrm{o}} 25.796$, no dia 10 de novembro do mesmo ano. O referido decreto reconheceu o direito de escolha do governo brasileiro sobre quais refugiados e deslocados entrariam no país e reafirmou a entrada do restante das pessoas cuja recepção já havia sido acordada no Acordo Brasil-Comitê Intergovernamental. Ademais, evidenciou a viabilidade de organizações ou particulares se responsabilizarem pela tutela dos refugiados que não pudessem comprovar sua própria subsistência, após a aprovação dos mesmos pelo governo (BRASIL, 1948). Contudo, vale ressaltar que, ao mostrar uma abertura no processo de recebimento dos refugiados, tendo a colaboração da sociedade civil, o governo reconhece a tutela dos mesmos por outras vias, mas retira sua responsabilidade sobre esta função.

O decreto supracitado ainda delineava o estabelecimento de uma Comissão Mista composta por um representante do governo brasileiro e um da Comissão Preparatória da OIR. A Comissão foi instalada no dia 15 de dezembro de 1948 e auxiliou o Departamento Nacional de Imigração e outros órgãos nas atividades de recepção de refugiados, reclassificação das profissões, encaminhamento, assistência, propaganda e ajuda financeira. Além disso, foram criadas subdelegacias para tratar questões locais e mais imediatas nos estados de São Paulo, Rio Grande do Sul, Rio de Janeiro, Paraná, Goiás, Santa Catarina e Bahia. A partir dessa Comissão, o Brasil passou a cumprir acordos com os organismos internacionais e a receber fluxos maiores de refugiados e deslocados. Entre dezembro de 1948 e agosto de 1949, estima-se a imigração de 14.016 pessoas, recepcionadas e encaminhadas para vários estados, em uma lista de 28 nacionalidades. Dentre os maiores fluxos, destacam-se os poloneses (5.468) e os húngaros (1.450). No entanto, em 1949, as atividades da 
Comissão foram encerradas, tendo como justificativas razões de ordem financeira (ANDRADE, 2005, p. 21-22).

Mesmo em 1948, o acordo com o Comitê Intergovernamental ainda não havia sido ratificado, assim como ocorria com a Constituição da OIR, da qual o Brasil era signatário. A questão econômica estava fortemente relacionada a essa situação, visto que o governo brasileiro visava ser compensado por sua adesão definitiva à OIR ao declarar que a imigração de refugiados não era uma questão relevante na orientação de sua política imigratória. Além disso, ao cooperar com as atividades da OIR, o Brasil estava atendendo a uma solicitação dos governos dos EUA e do Reino Unido. Assim, vale ressaltar que apesar de o Brasil não ter se tornado membro oficial da OIR, a organização internacional contribuiu para que milhares de refugiados ingressassem no país durante seu funcionamento (MOREIRA, 2012, p. 86).

Posteriormente, a falta de firme comprometimento jurídico do Brasil com a questão dos refugiados continuou latente em suas negociações e em seus reconhecimentos. A delegação brasileira participou da conferência internacional que aprovaria o texto da Convenção de $1951^{4}$ e votou a favor do mesmo, mas sua assinatura só ocorreu em 1952 e sua aprovação pelo Parlamento, em território nacional, em 1960, com o Decreto Legislativo $\mathrm{n}^{\circ} 11$, de 7 de julho do mesmo ano. Mesmo sendo o primeiro país na América do Sul a aprovar a Convenção, o governo optou pela adoção da "reserva geográfica" para a recepção de refugiados, isto é, reconheceria como refugiados apenas as pessoas de origem europeia (MOREIRA, 2012, p. 90-91).

\section{Ditadura Civil-Militar: enrijecimento da segurança nacional, repressão e resistência}

Considerando o contexto da Guerra Fria e, mais especificamente, a Revolução Cubana, de 1959, observa-se que a questão imigratória ganhou uma conotação mais rígida, mais militarizada de Segurança Nacional. O entendimento norte-americano de que a Revolução Cubana despertou e constatou a presença da ameaça comunista no extremo ocidente serviu como base para intensificar seus interesses estratégicos, dirigindo-se de forma mais incisiva para a América do Sul. Com isso,

\footnotetext{
${ }^{4}$ Segundo o parágrafo 2 do seu art. $1^{\circ}$ (A), refugiado seria toda pessoa que "em consequência dos acontecimentos ocorridos antes de $1^{\circ}$ de janeiro de 1951 e temendo ser perseguida por motivos de raça, religião, nacionalidade, grupo social ou opiniões políticas, se encontra fora do país de sua nacionalidade e que não pode ou, em virtude desse temor, não quer valer-se da proteção desse país, ou que, se não tem nacionalidade e se encontra fora do país no qual tinha sua residência habitual em consequência de tais acontecimentos, não pode ou, devido ao referido temor, não quer voltar a ele". Disponível em: http://www.acnur.org/t3/fileadmin/Documentos/portugues/BDL/Convencao_relativa_ao_Estatuto_dos_Refugiados.pdf? view $=1>$. Acesso em: 10 de novembro de 2017.

Compocs, v1, n 23 - jul -dez 2020
} 
as relações entre as Forças Armadas latino-americanas e os EUA foram reforçadas tanto através de programas de apoio militar quanto pelo aumento do número de oficiais latino-americanos que eram convidados a realizar estágios em escolas ou centros de treinamento norte-americanos (MENDES, 2013, p. 30).

A Doutrina da Segurança Nacional (DSN), criada pelos EUA no contexto da Guerra Fria, é uma ideologia que destaca uma guerra constante e total contra o comunismo, influenciando fortemente nas configurações políticas dos países da América do Sul. Ao se posicionar ao lado dos países do bloco ocidental, o governo brasileiro adotou a Doutrina da Segurança Nacional desde a criação da Escola Superior de Guerra, em 1949, tendo sua aplicação mais incisiva a partir de 1964, com a ditadura civil militar (BORGES, 2007, p. 36). Não obstante, cabe destacar que a noção de segurança nacional é uma questão latente no contexto brasileiro desde, principalmente, a Era Vargas, como já sinalizada nos decretos mencionados anteriormente e devidamente tipificada em leis.

Entender o funcionamento da DSN é de suma importância para analisar a lógica direcionada à política imigratória durante esse período, visto que suas ações ultrapassavam a operação militar, configurando-se também em uma guerra psicológica. A DSN promovia a desmoralização do inimigo para apartá-lo dos demais cidadãos, demonstrando que o inimigo interno não provém do povo, pois o verdadeiro povo possui um entendimento correto dos objetivos nacionais, isto é, está de acordo com aqueles indicados pelo governo. A partir dessa noção, o Estado aplicava uma política repressiva através de aparelhos de segurança e informação com a justificativa de defender a pátria de um inimigo (BORGES, 2007, p. 28-29).

Posto isso, ressalta-se que a DSN não reorientou somente a política nacional, servindo de parâmetro também para as relações internacionais do país, atingindo a política imigratória e, especificamente, a questão dos refugiados. Para restringir os pedidos de refúgio, utilizava-se a justificativa da manutenção da ordem pública e do combate do inimigo externo, visando evitar que esse inimigo, denominado comunista, se infiltrasse no território nacional e influenciasse em suas configurações internas, isto é, ameaçasse a supremacia da ditadura.

Colocar o inimigo como externo, mas passível de infiltração ou já infiltrado, respaldava o controle do Estado em todas as instâncias e possibilitava a seletividade quanto aos imigrantes que entrariam no país, sempre de acordo com os interesses nacionais.

Quando a seleção não era embasada categoricamente pelo fundamento da segurança nacional, os órgãos ministeriais acionavam o caráter técnico para guiar a política imigratória do país, utilizando-se das noções de proteção do trabalhador nacional, da coordenação da entrada e 
saída de recursos humanos, da suplementação de mão de obra nacional com técnicos especializados em profissões demandadas no mercado de trabalho nacional, da contribuição das correntes imigratórias para o desenvolvimento social e econômico de determinadas áreas do território nacional (MOREIRA, 2012, p. 99). Em vista disso, apartar o inimigo dos cidadãos não só corroborava o fundamento da segurança nacional, mas também o discurso nacionalista, a partir de uma ótica utilitarista, para convencer a população da positividade de sua política.

Ao utilizar argumentos pautados na defesa do trabalhador nacional e no desenvolvimento social e econômico do país - valores fortemente orientados por uma concepção economicista influenciada pelos ideais norte-americanos e pelo capital estrangeiro que adentrava no país -, uma ideologia tecnicista foi amplamente perpetuada no país, justificando a seletividade dos imigrantes que entrariam no país. Por conseguinte, priorizada e vista como positiva desde os primórdios do trabalho livre no Brasil, a imigração europeia, convertida em mão-de-obra, manteve sua preferência na entrada do país. Cabe notar que o reconhecimento do status de refugiado no Brasil continuou sendo fundamentado pela reserva geográfica da Convenção de 1951, considerando apenas aqueles de origem europeia.

Em 1967, segundo o Decreto-Lei $n^{\circ}$ 200, de 25 de fevereiro do mesmo ano, a política imigratória ficou sob o controle do Ministério do Trabalho e Previdência Social, envolvendo os Ministérios da Justiça, das Relações Exteriores, do Interior e da Saúde, responsáveis, respectivamente, pelos assuntos relativos à cidadania e nacionalidade, pela atribuição sobre serviços consulares, pelas funções relacionadas à radicação das populações, pela ocupação do território e migrações internas e pela vigilância sanitária de fronteiras (MOREIRA, 2012, p. 99). Além disso, o referido decreto criou o Conselho de Segurança Nacional, tendo como papel a assessoria na formulação e na conduta política de segurança nacional, e o Serviço Nacional de Informações, que atuaria na coordenação das atividades de informação e contrainformação referentes à segurança nacional (BRASIL, 1967).

Posteriormente, em 1969, o Decreto-Lei ${ }^{\circ}$ 941, de 13 de outubro do mesmo ano, regeu a situação jurídica do estrangeiro no Brasil, cuidando da admissão, dos direitos e deveres, infrações e penalidades, deportação, expulsão, extradição, naturalização. Seu art. $73^{\circ}$ definia que o estrangeiro que atentasse "contra a segurança nacional, a ordem política ou social, a tranquilidade e a moralidade pública e a economia popular, ou cujo procedimento o torne nocivo ou perigoso à conveniência e aos interesses nacionais" poderia ser expulso do território nacional (BRASIL, 1969). Tais especificações visavam preservar o controle político-ideológico da ditadura, dado que as normas eram definidas em congruência a política autoritária vigente, caracteristicamente 
anticomunista. Assim, todas as ações e ideologias consideradas subversivas foram colocadas sob a égide da segurança nacional e da ordem social e política para justificar a política imigratória restritiva do regime e suas repressões.

Mais tarde, com o Decreto $\mathrm{n}^{\circ}$ 66.689, de 11 de junho de 1970, foram acrescentadas novas finalidades à política imigratória, tais como "preservar a segurança nacional, a composição étnica do Brasil, sua organização institucional, e seus interesses políticos, socioeconômicos e culturais" (BRASIL, 1970). A “preservação da composição étnica” é colocada em pauta dentro de um contexto em que há um aumento do fluxo dos refugiados fora da Europa, principalmente por conta das descolonizações da África e da Ásia, o que demonstra uma resposta de cunho restritivo em relação a esses acontecimentos por parte do regime ditatorial. Portanto, o que se verifica é a preferência pela "preservação da ascendência europeia" através da política imigratória, inclusive na entrada de refugiados.

A título de exemplo, quando o Brasil autorizou a adesão do Protocolo sobre o Estatuto de Refugiados de 1967, pelo Decreto Legislativo $n^{\circ}$ 93, de 30 de novembro de 1971, e promulgou o mesmo através do Decreto $n^{\circ} 70.946$, de 7 de agosto de 1972, decidiu-se pela manutenção da reserva geográfica contida na Convenção de 1951 (BRASIL, 1971; Idem, 1972). Isto é, optou-se pela manutenção do reconhecimento apenas de refugiados de origem europeia, excluindo, por conseguinte, pessoas de origem africana, asiática e latino-americana, contrariando o princípio norteador do Protocolo ${ }^{5}$. Além disso, destaca-se que a opção pela manutenção da reserva está fortemente ligada ao contexto das ditaduras no Cone Sul, no qual houve um aumento do fluxo de refugiados latino-americanos por conta, principalmente, das perseguições dos governos ditatoriais na região.

Durante a década de 70, houve a intensificação em massa das ditaduras na América do Sul, fazendo com que muitos cidadãos buscassem refúgio em outros países da região para fugir das perseguições políticas das ditaduras de seus respectivos países. E no Brasil não foi diferente. A conjuntura brasileira, na época, tornou-se um entrave ao desenvolvimento de sua política de proteção internacional aos refugiados, uma vez que foi gerado um movimento contrário no país, isto é, muitos cidadãos brasileiros foram forçados a irem para o exterior em função das perseguições da

\footnotetext{
${ }^{5}$ Cf. Artigo I. (1) do Protocolo de 1967, que adere a todos os artigos da Convenção de 1951, excetuando os da reserva geográfica (reconhecimento de refugiados de origem europeia) e temporal (referente a acontecimento anteriores a data

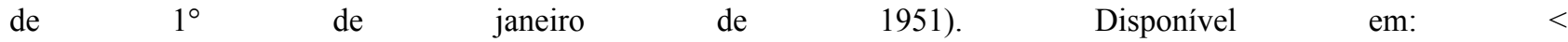
http:/www.acnur.org/fileadmin/scripts/doc.php?file=fileadmin/Documentos/portugues/BD_Legal/Instrumentos_Interna cionais/Protocolo_de_1967>. Acesso em 12 de novembro de 2017.

Compocs, v1, n 23 - jul -dez 2020
} 
ditadura (BARRETO, 2010, p. 17). Portanto, analisa-se que o Brasil, além de dirigir uma política imigratória restritiva, ainda se transformou em um país que gerava refugiados.

Assim, ao considerar o contexto das ditaduras no Cone Sul, no qual muitos perseguidos políticos buscaram refúgio em outros países da região, observa-se que a Doutrina da Segurança Nacional ganhou outras proporções. A Operação Condor, por exemplo, criada na década de 1970 através da cooperação clandestina e à margem da lei entre as ditaduras estabelecidas nos países do Cone Sul - Argentina, Bolívia, Brasil, Chile, Uruguai e Paraguai - com a finalidade de trocar informações, sequestrar, torturar, assassinar adversários políticos que faziam oposição aos regimes ditatoriais da região. Essas operações clandestinas deram margem à graves violações aos direitos humanos de cidadãos brasileiros no exterior e de estrangeiros no Brasil. ${ }^{6}$

Constata-se que havia um movimento significante de refugiados no Brasil advindos de países vizinhos que também passavam por ditaduras. Essa situação era decorrente da ausência de condições financeiras ou documentais para que se assentassem em países mais distantes, que não estivessem passando por um regime de exceção (BARRETO, 2010, p. 17). Consequentemente, por terem contestado as ditaduras de seus países de origem e estarem fugindo de contextos de repressão semelhantes ao do Brasil, os refugiados da América do Sul eram vistos pela ditadura brasileira como uma ameaça ao regime. Além disso, o contato dos refugiados políticos com a militância era um fator que preocupava as autoridades brasileiras, uma vez que possuíam mais experiências com ações mais estratégicas.

No início da década de 1970, o papel do Alto Comissariado das Nações Unidas para os Refugiados (ACNUR) no Brasil consistia somente no acompanhamento da movimentação dos refugiados, tendo a sociedade civil, com a Igreja Católica como seu principal expoente, tomado a frente na proteção dos brasileiros durante a ditadura, auxiliando em seus refúgios no exterior. A Cáritas Arquidiocesana do Rio de Janeiro e a de São Paulo, desde 1975, ajudavam argentinos, chilenos, uruguaios que buscavam refúgio no Brasil, ainda que não fossem reconhecidos pelo governo por conta da reserva geográfica e com o risco de serem entregues ao governo do país de origem, caso fossem descobertos (BARRETO, 2010, p. 17).

Em 1977, em São Paulo, a Comissão Justiça e Paz também entrou nesse mérito, junto com o grupo CLAMOR, criado com o objetivo de denunciar violações de direitos humanos no Cone Sul.

\footnotetext{
${ }^{6}$ Ver mais em: Comissão Nacional da Verdade. Operação Condor e a Ditadura no Brasil: análise de documentos desclassificados. Disponível em: $<$ http://cnv.memoriasreveladas.gov.br/index.php/2-uncategorised/417-operacao-condor-e-a-ditadura-no-brasil-analise-d e-documentos-desclassificados $>$. Acesso em: 11 de maio de 2018.

Compocs, v1, n 23 - jul -dez 2020
} 
Paralelamente, o Escritório do Programa das Nações Unidas para o Desenvolvimento (PNUD) no Rio de Janeiro também estava recebendo solicitantes de refúgio sul-americanos. Como não possuía condições para lidar adequadamente com os problemas, o PNUD solicitou ajuda ao ACNUR com a vinda de um funcionário experiente do Alto Comissariado para negociar com as autoridades locais e encontrar soluções para a situação. Em vista disso, o ACNUR deu início aos seus trabalhos no Brasil em 1977, em caráter emergencial, mas não obteve autorização das autoridades brasileiras para o estabelecimento de um escritório independente em território nacional, o que ocorreu apenas em 1982 (MOREIRA, 2012, p. 116).

Tendo forte apoio do governo norte-americano contra a ameaça comunista e amparado pela imprensa nacional, o regime ditatorial, nos anos iniciais, buscou consolidar sua política imigratória sem ter que lidar com a problemática dos refugiados de forma mais incisiva. Tratar a questão traria mais visibilidade para sua política repressiva frente à comunidade internacional, tendo em conta a grande violação dos direitos humanos nesse período, tanto dos cidadãos brasileiros quanto dos estrangeiros considerados subversivos. Por conseguinte, a alternativa do governo para conciliar suas relações diplomáticas internacionais com a política repressiva adotada no âmbito nacional foi aceitar a atuação do ACNUR no país, mesmo que de forma restrita, para demonstrar, formalmente, sua dedicação na temática.

Por meio de um acordo de caráter limitado com o governo brasileiro, o ACNUR teve como sua principal tarefa reassentar os refugiados que buscavam proteção no país e não eram se encaixavam no regimento, tendo em vista que o governo brasileiro não queria latino-americanos em seu território “com a mesma coloração política daqueles que ele mesmo perseguia" (HAYDU, 2011, p. 133). Liberado para realizar o processo de elegibilidade dos solicitantes de refúgio no Brasil, o ACNUR reconhecia o estatuto de refugiado segundo seu mandado, ficando responsável pelos chamados "refugiados mandatários". Era sob esse critério que os sul-americanos ficavam sob suaproteção até que a agência conseguisse reassentamento em outros países (MOREIRA, 2012, p. 119).

As autoridades brasileiras pressionavam para que o reassentamento de latino-americanos fosse realizado de maneira breve, utilizando a reserva geográfica como justificativa. Cabe ressaltar que o ACNUR compartilhava, de alguma maneira, da preocupação do governo brasileiro em relação à dificuldade de lidar com os refugiados latino-americanos, tendo em conta suas experiências com atividades de militância política que auxiliavam nas articulações para demandar segurança e melhores condições econômicas no país, por vezes consideradas exageradas pelo órgão. Contudo, a agência tinha a cautela de não revelar seus nomes às autoridades brasileiras, em função 
da segurança dos mesmos, uma vez que poderia haver uma comunicação entre os governos ditatoriais para delatá-los (MOREIRA, 2012, p. 129-134).

A partir de 1980 a situação jurídica do estrangeiro no Brasil passou a ser regida pelo Decreto-Lei $\mathrm{n}^{\circ}$ 6.815, de 19 de agosto do mesmo ano, ficando conhecida como Estatuto do Estrangeiro. $\mathrm{O}$ art. $1^{\circ}$ instituía que "em tempo de paz, qualquer estrangeiro poderá, satisfeitas as condições desta Lei, entrar e permanecer no Brasil e dele sair, resguardados os interesses nacionais". Para reforçar essa tendência, o art. $2^{\circ}$ colocava como condição para a aplicação da Lei a atenção “à segurança nacional, à organização institucional, aos interesses políticos, socioeconômicos e culturais do Brasil, bem assim à defesa do trabalhador nacional". A referida lei também criou o Conselho Nacional de Imigração (CNI), tendo como função orientar, coordenar e fiscalizar as atividades de imigração. Ademais, também estabeleceu que a Secretaria Geral do Conselho de Segurança Nacional mantivesse um observador junto ao Conselho Nacional de Imigração (BRASIL, 1980).

Nota-se que o Decreto supracitado se orienta intensamente pela Doutrina da Segurança Nacional para justificar os critérios da abertura da política imigratória do país. Ao difundir uma ideologia de guerra iminente, em que a "paz" não está garantida, o regime leva ao entendimento de que a nação está ameaçada e precisa ser defendida de algum inimigo. Para tornar essa concepção mais próxima da população brasileira, coloca-se o trabalhador nacional como representante da nação que precisa ser defendida. Não obstante, atribuir um olhar para os trabalhadores nacionais neste contexto favorece a busca pela adesão dos mesmos para fortalecer esse posicionamento e revigorar o projeto dito nacionalista promovido pelo regime. Em contraposição, os imigrantes são colocados na posição de possíveis inimigos, passíveis de ameaçar tanto o campo socioeconômico quanto o político, colocando a aplicação da política imigratória em constante indeterminação.

Ademais, colocar o critério cultural em questão demonstra o viés de xenofóbico do regime, que é uma herança de longa data das políticas imigratória brasileiras, como já evidenciado em contextos anteriores.

$\mathrm{O}$ art. 65 do Decreto-Lei $\mathrm{n}^{\circ}$ 6.815, além de reforçar alguns critérios para extradição já citados nos anteriores, inclui imigrantes em situações de "vadiagem" ou "mendicância", ignorando totalmente o teor humanitário. $\mathrm{O}$ art. 106 ainda veta a participação de imigrantes em qualquer "representação de sindicato ou associação profissional, bem como de entidade fiscalizadora do exercício de profissão regulamentada", e o art. 107 estende à organização de "desfiles, passeatas, comícios e reuniões de qualquer natureza” (BRASIL, 1980). Portanto, além de uma política 
imigratória seletiva para a entrada de imigrantes, observa-se que há uma política repressiva em relação às liberdades dos mesmos em território nacional.

Promove-se, portanto, a ideia de que é necessário ter um regime sólido para proteger a nação, tornando nítida a posição defensiva do regime a fim de impedir que sua soberania fosse ameaçada. Em vista disso, aproveita-se da conjuntura de guerras civis ocorrendo pelo mundo e da Guerra Fria para colocar as desconfianças sobre os imigrantes e os refugiados políticos que podem vir a se infiltrar em território nacional, conspirar e subverter a ordem.

\section{Redemocratização: processo lento e gradual de democratização dos direitos dos refugiados}

O caminho de redemocratização percorrido pelo Brasil fez com que muitas questões relativas aos refugiados fossem flexibilizadas. Contudo, a preferência pela reserva geográfica foi mantida. A posição do Brasil frente à reserva seguiu um fluxo contrário ao de um contexto mais amplo, em termos de América Latina, visto que havia a movimentação de esforços para que os direitos dos refugiados fossem repensados e estendidos. A Declaração de Cartagena, de 19847, é um exemplo desta perspectiva, visando considerar as novas dimensões do fluxo de refugiados e considerar, principalmente, o cenário da América Latina.

A conferência que aprovou seu texto contava com representantes governamentais e especialistas de Belize, Colômbia, Costa Rica, El Salvador, Guatemala, Honduras, México, Nicarágua, Panamá e Venezuela. Além de não participar da reunião em que o texto da Declaração foi aprovada, o Brasil não assinou a mesma nesse período (MOREIRA, 2012, p. 172).

Com a Constituição Federal de 1988, houve a sinalização da importância dos direitos humanos e da concessão de asilo político como princípios norteadores das relações internacionais. Estima-se que no período de 1985-87 1,2 milhão de pessoas emigraram do Brasil em busca de melhores oportunidades no exterior, assim, viu-se necessária uma revisão no tratamento dado aos imigrantes e refugiados no país em vista da reciprocidade internacional, isto é, tratar a questão não

\footnotetext{
${ }^{7}$ O instrumento estende a conceituação de refugiado da Convenção de 1951 e do Protocolo de 1967, sem as reservas, para todas "as pessoas que tenham fugido dos seus países porque a sua vida, segurança ou liberdade tenham sido ameaçadas pela violência generalizada, a agressão estrangeira, os conflitos internos, a violação maciça dos direitos humanos ou outras circunstâncias que tenham perturbado gravemente a ordem pública”. Disponível em: $<$ http://www.acnur.org/t3/fileadmin/Documentos/portugues/BD_Legal/Instrumentos_Internacionais/Declaracao_de _Cartagena.pdf?view=1>. Acesso em: 05 de dezembro de 2017.
} 
mais sob a ótica da segurança nacional, mas da perspectiva humanitária, dos direitos humanos. Assim, o Itamaraty elaborou a Exposição de Motivos de 01 de dezembro de 1989, propondo o levantamento da reserva geográfica, o que veio a se concretizar com o Decreto n. 98.602, de 19 de dezembro de 1989. Contudo, tal decreto desconsiderou os artigos 15 e 17 da Convenção, que consistem em um tratamento aos refugiados igual ao concedido aos estrangeiros em geral e livre e fácil acesso aos tribunais, igualmente aos nacionais. Posteriormente, o Decreto $n^{\circ} 99.757$ de 1990, retificou o previsto no Decreto $n^{\circ} 98.602$ de 1989, aplicando os artigos 15 e 17 da Convenção aos refugiados no país (MOREIRA, 2012, p. 173-175).

O levantamento da reserva geográfica foi resultado, principalmente, de diversas gestões do ACNUR e do apoio de instituições da sociedade civil, incluindo as da Igreja Católica. Também teve o auxílio do Itamaraty enquanto interlocutor do governo brasileiro. A partir disso, mais pessoas puderam obter o estatuto de refugiado no Brasil, uma vez que também se passou a considerar a definição ampliada de refugiados contida na Declaração de Cartagena. Além disso, o fim da Guerra Fria levou a grandes transformações internacionais no que se refere ao a percepção da categoria de refugiado, pois o fim da disputa entre os dois blocos fez com que os refugiados perdessem a carga ideológica e política que orientou o período de forma tão incisiva. Contudo, o embate cultural entre refugiados e sociedades receptoras continuou crescendo (MOREIRA, 2012, p. 177-183).

Em 1991, o Ministério da Justiça editou a portaria interministerial n ${ }^{\circ} 394$, com o dispositivo jurídico de proteção a refugiados, estabelecendo uma dinâmica processual para a solicitação e concessão de refúgio e criando um marco jurídico interno mínimo. Inicialmente, o ACNUR ficava responsável pela entrevista dos solicitantes de refúgio e pedia o reconhecimento formal para o governo brasileiro. Este, portanto, tinha o papel limitado à liberação dos documentos. Mais tarde, a Lei $\mathrm{n}^{\circ}$ 9.474, de 22 de julho de 1997, estabeleceu o Estatuto dos Refugiados, como ficou conhecido, que foi redigido em parceria com o ACNUR e com representantes da sociedade civil. O instrumento incorporou os dispositivos de proteção internacional de refugiados e criou o Comitê Nacional para os Refugiados. Este dita a política pública do refúgio e toma decisões quanto às solicitações de refúgio apresentadas no Brasil, contando com representantes do Estado, da sociedade civil e da comunidade internacional. Em vista disso, é denominado um órgão tripartite e, por comportar o público e o privado, chamado de misto (BARRETO, 2010, p. 18-19).

Além de o Estatuto dos Refugiados reconhecer a definição de refugiado presente na Convenção e no Protocolo, estende a condição contida na Declaração de Cartagena, que considera também "graves e generalizadas violações de direitos humanos", segundo seu art. $1^{\circ}$ (BRASIL, 1997). Com este instrumento, o Estado assume a política de refugiados como parte de sua agenda e 
transforma o procedimento de reconhecimento da condição de refugiado em uma questão muito mais técnico-jurídica. Ademais, democratiza a decisão do reconhecimento ao contar com a participação da sociedade civil organizada e do órgão internacional.

\section{Considerações finais}

Entende-se que, durante o período analisado neste trabalho, houve ocasionais exceções quanto à entrada de imigrantes e, especificamente, refugiados no Brasil. Assim, encontram-se casos de refugiados de origem não europeia que adentraram no país, seja de forma transitória para o reassentamento em outro país ou de forma a permanecer em território nacional a título humanitário excepcional. Assim, a permanência de muitos se deu, por exemplo, em razão do apoio fornecido por organizações da sociedade civil, como ilustrado através da Cáritas e pela ajuda de órgãos internacionais, como o ACNUR, na modalidade de refugiados mandatários.

Neste primeiro trabalho, atesta-se a existência de um padrão referente aos parâmetros adotados pelos governos brasileiros, de várias épocas, na aplicação da política imigratória e, consequentemente, na política de refugiados. Os fundamentos norteadores destas políticas giravam em torno da eugenia, da segurança nacional e da ótica econômica, que ora se mesclavam. A combinação de tais era orientada pelos interesses das autoridades brasileiras, elevados a título de interesse nacional.

A herança racista do pensamento escravocrata que marcou fortemente os séculos anteriores à Primeira República se mostrou presente, de forma mais ou menos ativa, em vários períodos da história do país. A concepção racista foi adaptada ao trabalho assalariado, desvalorizando a mão de obra nacional, principalmente da população negra ex escrava, e apreciando a europeia em prol do "desenvolvimento" da nação em seus vários aspectos, isto é, de um ideal de branqueamento. A partir da ascensão das teses eugenistas, a imigração passou a ser considerada de forma mais intencionada pelas autoridades, em especial porque contemplava outro importante campo já visado: a colonização do território.

Direcionar a imigração para a ocupação do território nacional fortaleceu os propósitos da política promovida pelos governos brasileiros. Paralelamente, havia a preocupação com a formação de grupos étnicos que dificultavam, segundo as autoridades, a "assimilação" ao povo brasileiro, uma vez que se buscava a construção de uma "brasilidade" que atendesse aos interesses nacionais. Ou seja, que fosse voltada para os ideais eugenistas e congruente com a orientação político-ideológica do governo, explicitamente anticomunista. O fundamento da segurança nacional 
foi uma peça chave para assegurar a soberania do governo, colocando como subversivos todos aqueles considerados ameaças aos seus interesses ou como indesejáveis aqueles que não atendiam ao projeto nacionalista, de acordo com os critérios político-ideológico, étnico-racial, religioso, moral ou utilitarista, que, por sua vez, estavam em constante diálogo com as pressões do contexto internacional.

Enquanto a questão dos refugiados ganhava espaço na agenda internacional, o Brasil buscou se distanciar ao máximo de sua formalização como política de Estado, dado que o mesmo colocava em prática políticas altamente repressivas, principalmente durante a Era Vargas e a ditadura civil-militar iniciada em 1964. Durante a vigência desses regimes, houve a violação dos direitos humanos da população brasileira em muitos aspectos. Portanto, tratar da questão dos refugiados traria mais atenção para o contexto nacional, dificultando o equilíbrio entre suas linhas ditatorial e diplomática. Quando cedeu à reserva geográfica e institucionalizou a política de refugiados, o país passou a tratar da questão de forma mais humanitária. Contudo, os parâmetros utilizados anteriormente na política de refugiados foram enraizados em muitos segmentos institucionais e, consequentemente, da sociedade civil, o que pode explicar o levantamento de tais critérios na atualidade, tanto no âmbito internacional quanto no nacional, em relação aos novos fluxos de refugiados.

\section{Referências}

Andrade, José H. Fischel de (2005). "O Brasil e a organização internacional para os refugiados (1946-1952)”. In: Rev. Bras. Polít. Int. Brasília, v. 48, n. 1, p. 60-96.

Barreto, Luiz Paulo Teles F (2010). “A Lei Brasileira de Refúgio - Sua história”. In: Barreto, Luiz (org.). Refúgio no Brasil: a proteção brasileira aos refugiados e seu impacto nas Américas. Brasília: ACNUR, Ministério da Justiça, p. 10-21.

Borges, Nilson (2007). “A Doutrina de Segurança Nacional e os Governos Militares”. In: O Brasil Republicano. 2 ed. Rio de Janeiro: Civilização Brasileira, p. 13-42.

Brasil. Constituição da República Federativa do Brasil. 1934. Disponível em: $<$ http://www2.camara.leg.br/legin/fed/consti/1930-1939/constituicao-1934-16-julho-1934-365196-p ublicacaooriginal-1-pl.html>. Acesso em 18 de fevereiro de 2018.

Constituição da República Federativa do Brasil. 1937. Disponível em: $<\mathrm{http}: / /$ www.planalto.gov.br/ccivil_03/constituicao/constituicao37.htm>. Acesso em 19 de fevereiro de 2018. 
. Constituição da República Federativa do Brasil. 1946. Disponível em: $\overline{<\mathrm{http}: / / w w w 2 . c a m a r a . l e g . b r / l e g i n / f e d / c o n s t i / 1940-1949 / c o n s t i t u i c a o-1946-18-j u l h o-1946-365199-p ~}$ ublicacaooriginal-1-pl.html >. Acesso em 23 de fevereiro de 2018.

Decreto n. 528 de 28 de junho de 1890. Disponível em: <http://www2.camara.leg.br/legin/fed/decret/1824-1899/decreto-528-28-junho-1890-506935-public acaooriginal-1-pe.html>. Acesso em: 20 de fevereiro de 2018.

Decreto n. 4.247 de 6 de janeiro de 1921. Disponível em: <http://www2.camara.leg.br/legin/fed/decret/1920-1929/decreto-4247-6-janeiro-1921-568826-publi cacaooriginal-92146-pl.html>. Acesso em: 20 de fevereiro de 2018.

Decreto n. 24.215 de 9 de maio de 1934. Disponível em:

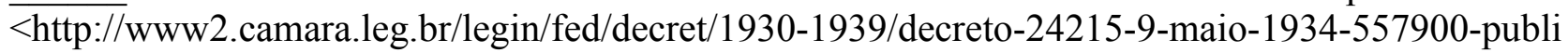
cacaooriginal-78647-pe.html>. Acesso em: 20 de fevereiro de 2018. [1934a]

Decreto n. 24.258 de 16 de maio de 1934. Disponível em: $<$ http://www2.camara.leg.br/legin/fed/decret/1930-1939/decreto-24258-16-maio-1934-557864-publ icacaooriginal-78583-pe.html>. Acesso em: 20 de fevereiro de 2018. [1934b]

Decreto n. 3.691 de 6 de fevereiro de 1939. Disponível em:

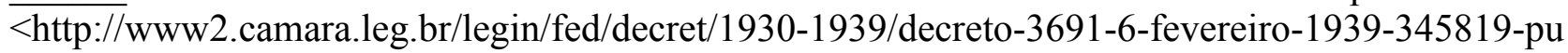
blicacaooriginal-1-pe.html>. Acesso em: 21 de fevereiro de 2018.

Decreto n. 25.796 de 10 de novembro 1948. Disponível em: $\overline{<\mathrm{http}: / / w w w 2 . c a m a r a .1 e g . b r / l e g i n / f e d / d e c r e t / 1940-1949 / d e c r e t o-25796-10-n o v e m b r o-1948-455070 ~}$ -publicacaooriginal-1-pe.html>. Acesso em: 22 de fevereiro de 2018.

. Decreto n. 66.689 de 11 de junho de 1970. Disponível em:

$\overline{<h t t p: / / w w w 2 . c a m a r a . l e g . b r / l e g i n / f e d / d e c r e t / 1970-1979 / d e c r e t o-66689-11-j u n h o-1970-408279-p u b ~}$ licacaooriginal-1-pe.html>. 24 de fevereiro de 2018.

Decreto $\mathrm{n}^{\circ} \mathbf{7 0 . 9 4 6}$ de 7 de agosto de 1972. Disponível em:

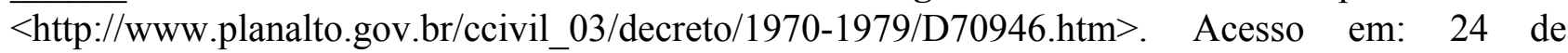
fevereiro de 2018.

Decreto-Lei $n \quad 406$ de 4 de maio de 1938 . Disponível em: $\overline{<h t t p: / / w w w 2 . c a m a r a . l e g . b r / l e g i n / f e d / d e c l e i / 1930-1939 / d e c r e t o-l e i-406-4-m a i o-1938-348724-p u b l i ~}$ cacaooriginal-1-pe.html>. Acesso em: 21 de fevereiro de 2018.

Decreto-Lei n. 3.175 de 7 de abril de 1941. Disponível em: $\overline{<\mathrm{http}: / / w w w 2 . c a m a r a . l e g . b r / l e g i n / f e d / d e c l e i / 1940-1949 / d e c r e t o-l e i-3175-7-a b r i l-1941-413194-p u b l ~}$ icacaooriginal-1-pe.html $>$. Acesso em: 21 de fevereiro de 2018.

Decreto-Lei n. 7.575 de 21 de maio de 1945. Disponível em: $\overline{<\mathrm{http}: / / w w w 2 . c a m a r a .1 e g . b r / l e g i n / f e d / d e c l e i / 1940-1949 / d e c r e t o-l e i-7575-21-m a i o-1945-417343-p u ~}$ blicacaooriginal-1-pe.html>. Acesso em: 22 de fevereiro de 2018. [1945b]

Decreto-Lei n. 7.967 de 18 de setembro de 1945. Disponível em: $\overline{<\mathrm{http}: / /}$ www.planalto.gov.br/ccivil_03/decreto-lei/1937-1946/Del7967.htm>. Acesso em: 22 de fevereiro de 2018. [1945b] 
Decreto-Lei n. 200 de 25 de fevereiro de 1967. Disponível em: $\overline{<\mathrm{http}: / / w w w 2 . c a m a r a . l e g . b r / l e g i n / f e d / d e c l e i / 1960-1969 / d e c r e t o-l e i-200-25-f e v e r e i r o-1967-376033-~}$ norma-pe.html>. Acesso em: 24 de fevereiro de 2018.

Decreto-Lei n. 941 de 13 de outubro de 1969. Disponível em: <http://www2.camara.leg.br/legin/fed/declei/1960-1969/decreto-lei-941-13-outubro-1969-375371-n orma-pe.html>. Acesso em: 24 de fevereiro de 2018.

Decreto-Lei $\mathrm{n}^{\circ} \mathbf{6 . 8 1 5}$ de 19 de agosto de 1980. Disponível em:

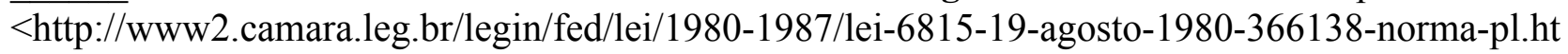
$\mathrm{ml}>$. Acesso em: 25 de fevereiro de 2018.

Decreto Legislativo n. 93 de 30 de novembro de 1971. Disponível em:

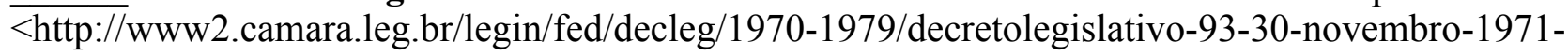
346286-publicacaooriginal-1-pl.html>. Acesso em: 24 de fevereiro de 2018.

Lei n. 38 de 4 de abril de 1935. Disponível em:

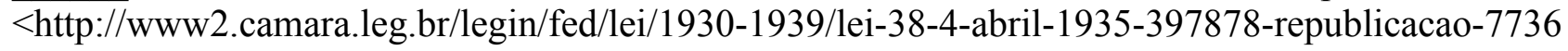
7-pl.html>. Acesso em: 21 de fevereiro de 2018.

Lei n. 9.474 de 22 de julho de 1997. Disponível em: $\overline{<\mathrm{http} / / /}$ www.planalto.gov.br/ccivil_03/leis/19474.htm>. Acesso em: 28 de fevereiro de 2018.

Capelato, Maria Helena Rolim (2003). “O Estado Novo: o que trouxe de novo?”. In: Ferreira, Jorge e Delgado, Lucília de Almeida Neves (orgs.), O Brasil Republicano - o tempo do

nacional-estatismo. Rio de Janeiro: Civilização Brasileira, p. 107- 143.

Carneiro, Maria Luiza Tucci (1994). "República, identidade nacional e anti-semitismo (1930-1945)". In: Revista de História, São Paulo, n. 129-131, p. 153-163.

Comissão Nacional da Verdade. Operação Condor e a Ditadura no Brasil: análise de documentos desclassificados.

Disponível

em:

$<$ http://cnv.memoriasreveladas.gov.br/index.php/2-uncategorised/417-operacao-condor-e-a-ditadura -no-brasil-analise-de-documentos-desclassificados>. Acesso em: 11 de maio de 2018.

Convenção Relativa ao Estatuto dos Refugiados. Disponível em: < http://www.acnur.org/t3/fileadmin/Documentos/portugues/BDL/Convencao_relativa_ao_Estatuto_d os_Refugiados.pdf?view=1>. Acesso em 10 de novembro de 2017.

Declaração de Cartagena de 1984. Disponível em: $<$ http://www.acnur.org/t3/fileadmin/Documentos/portugues/BD_Legal/Instrumentos_Internacionais /Declaracao_de_Cartagena.pdf?view=1>. Acesso em: 05 de dezembro de 2017.

Gomes, Angela (1999). "Ideologia e trabalho no Estado Novo". In: Pandolfi, Dulce (org.), Repensando o Estado Novo. Rio de Janeiro: FGV, p. 53-72. 
Grinberg, K (2000). "Nova língua interior. 500 anos de história dos judeus no Brasil”. In: IBGE, Brasil: 500 anos de povoamento. Rio de Janeiro: IBGE, 123-139.

Guimarães; Vainfas (2000). "Sonhos galegos: os espanhóis no Brasil”. In: IBGE, Brasil: 500 anos de povoamento. Rio de Janeiro: IBGE, p. 101-121.

Haydu, Marcelo (2011). "A integração de refugiados no Brasil”. In: Ramos, André de Carvalho; Rodrigues, Gilberto; Almeida, Guilherme Assis de (orgs.), 60 anos de ACNUR: perspectivas de futuro. São Paulo: Editora CL-A Cultural, p. 131-146.

Koifman, Fábio (2017). "O Estado Novo e as restrições à entrada de refugiados: história e construção de memória”. In: Acervo, Rio de Janeiro, v. 30, n. 2, p. 71-88.

Maio, Marcos Chor (1999). "Qual anti-semitismo? Relativizando a questão judaica no Brasil dos anos 30". In: Pandolfi, Dulce (org.), Repensando o Estado Novo. Rio de Janeiro: FGV, p. 229-256.

Moreira, Julia Bertino (2012). Política em relação aos refugiados no Brasil (1947-2010). Tese de doutorado apresentada ao Programa de Pós-Graduação em Ciência Política do Instituto de Filosofia e Ciências Humanas da UNICAMP. Campinas.

Seyferth, Giralda (1997). “A assimilação dos imigrantes como questão nacional”. In: Mana, Rio de Janeiro, v. 3, n. 1, p. 95-131.

(2002). “Colonização, imigração e a questão racial no Brasil”. In: Revista USP, Brasil, n. $\overline{53, \text { p. } 117-149 .}$

Vainer, Carlos B (1990). "Estado e raça no Brasil: Notas exploratórias”. In: Estudos afro-asiáticos, n. 18 , p. 103-18.

Compocs, v1, n 23 - jul -dez 2020 